\title{
Морфология и круг хозяев Ampelomyces quisqualis Ces. ex Schlecht. в Заилийском Алатау
}

\section{The morphology and range of hosts Ampelomyces quisqualis Ces. ex Schlecht. in Trans-Ili Alatau}

\author{
Кызметова Л. А.', Рахимова Е. В. ${ }^{1,2}$, Джетигенова У. К. ${ }^{1}$, Сыпабеккызы Г. ${ }^{1,2}$ \\ Kyzmetova L. A. ${ }^{1}$, Rakhimova E. V. ${ }^{1,2}$, Dzhetigenova U. K. ${ }^{1}$, Sypabekkyzy G. ${ }^{1,2}$ \\ ${ }^{1}$ Институт ботаники и фитоинтродукиии, г. Алматы, Казахстан.E-mail: lyzka79@mail.ru; uldai7@mail.ru \\ ${ }^{2}$ КазНУ им. аль-Фараби, г. Алматы, Казахстан.E-mail: evrakhim@mail.ru; gulnaz_92_21@mail.ru \\ ${ }^{1}$ Institute of Botany and Phytointroduction, Almaty, Kazakhstan \\ ${ }^{2}$ Institute of Botany and Phytointroduction, Al-Farabi KazNU, Almaty, Kazakhstan
}

\begin{abstract}
Peфepam. Анализ полученных данных показал, что гиперпаразит Ampelomyces quisqualis Ces. ex Schlecht. чаще всего встречается на возбудителях мучнистой росы у растений семейств Asteraceae и Lamiaceae. Bпервые Ampelomyces quisqualis обнаружен на возбудителях мучнистой росы на представителях семейств Elaeagnaceae и Нуреricaceae. Гиперпаразит был обнаружен на 10 различных видах мучнисторосяных грибов, наиболее часто - на представителях рода Erysiphe. Размеры пикнид варьировали в диапазоне 30,0-105,0 × 25,0-50,0 мкм и конидий 3,5-7,0 × 1,5-3,5 мкм. Размеры пикнид Ampelomyces quisqualis на различных хозяевах близки между собой, однако большие размеры пикнид наблюдаются на Hieracium virosum Pall., а меньшие - на Stachys sylvatica L.
\end{abstract}

Ключевые слова. Гиперпаразит, конидии, мицелий, мучнистая роса, пикниды, растение-хозяин, Ampelomyces quisqualis.

Summary. Analysis of the obtained data showed that hyperparasite Ampelomyces quisqualis was most often found on powdery mildew pathogens on plants of the families Asteraceae and Lamiaceae. Ampelomyces quisqualis was first detected on powdery mildew pathogens on members of the Elaeagnaceae and Hypericaceae families. Hyperparasite was found on 10 different species of powdery mildew fungi, most often on representatives of the genus Erysiphe. Pycnidia sizes varied in the range of 30.0-105.0 $\times 25.0-50.0 \mu \mathrm{m}$ and conidia $-3.5-7.0 \times 1.5-3.5 \mu \mathrm{m}$. Ampelomyces quisqualis pycnidia sizes on different hosts were close to each other, however, big pycnidia sizes were observed on Hieracium virosum, and small sizes were observed on Stachys sylvatica.

Key words. Ampelomyces quisqualis, conidia, host-plant, hyperparasite mycelium, powdery mildew, pycnidia.

Заилийский Алатау - один из хребтов Северного Тянь-Шаня. Его длина с запада на восток составляет почти 380 км, ширина 30-40 км. Собственно Заилийский Алатау доходит на востоке до р. Тургень, постепенно снижаясь, и распадается на несколько отрогов: Бакай, Богуты, Сюгаты, Далашик, Сарытау и Турайгыр, а на западе продолжением основного хребта являются хребет Жетыжол, массив Кендыктас и Чу-Илийские горы (Рахимова и др., 2014).

Ampelomyces quisqualis - паразит на анаморфах и телеоморфах сумчатых грибов порядка Erysiphales. На белом налете мучнисто-росяных грибов при поражении их этим грибом образуются грязновато-серые пятна, постепенно увеличивающиеся в размерах и часто покрывающие весь налет. На поверхности мицелия хозяина, а также в его гифах, конидиях и клейстотециях образуются пикниды гиперпаразита. Они одиночные, шаровидные или вытянутые до грушевидных, иногда с сосочковидным апикальным выростом, бледно-бурые, однокамерные, до 40-105 мкм длиной, 30-50 мкм шириной, светло-коричневые или коричневые, с четким сетчатым рисунком на поверхности. Конидии выделяются из них сильной струей, образуя вокруг пикнид споровую массу. Конидии от цилиндрических до веретеновидных, прямые или слегка согнутые, одноклеточные, тонкостенные, гладкие, почти бесцветные 
или со слабым буроватым оттенком (Мельник, 1997). Конидии гиперпаразита переносятся каплями дождя и заражают новые пятна мучнистой росы. Их заражение происходит путем прорастания конидий, образования ростковых трубок, которые разрушают клеточную оболочку хозяина и проникают внутрь его клеток. Эндогенная грибница проходит все стадии развития в клетках хозяина, восприимчивость которых у одних видов больше в старом возрасте, а у других - в молодом, а клейстотеции всегда легче заражаются молодыми (Emmons, 1930). Гиперпаразит можно обнаружить на мучнисторосяных грибах с начала лета и до осени. Зимует он в клейстотециях на листьях и в почках некоторых видов растений (Рудаков, 1981). Биоконтролирующий потенциал, т. е. способность паразитировать и предотвращать распространение мучнистой росы, а также простота поиска в природе и выращивания на искусственных средах, обусловливают перспективность использования Ampelomyces quisqualis этого рода в биологической защите растений.

О микофильных грибах (гиперпаразитах) в Казахстане сведений очень мало. В основном приводятся данные о видах, паразитирующих на представителях мучнисторосяных грибов (Бызова и др., 1967). Для микобиоты Заилийского Алатау указаны 3 вида на гифах и конидиях Erysiphales. Однако эти сведения достаточно устарели, поскольку многочисленные представители рода Cicinnobolus в настоящее время считаются синонимами вида Ampelomyces quisqualis (Мельник, 1997). Целью работы являлось изучение морфологии и круга хозяев гиперпаразита Ampelomyces quisqualis на территории Заилийского Алатау.

Материалом для статьи послужили собственные сборы авторов из района исследований по программе «Реализация Государственными ботаническими садами приоритетных для Казахстана научно-практических задач Глобальной стратегии сохранения растений как устойчивой системы поддержания биоразнообразия (BR0523654)». Приготовление препаратов осуществлялось по стандартной методике (Поликсенова и др., 2004). Образцы изучались и фотографировались с помощью фотомикроскопа Polyvar (Reichert-Jung, Австрия) с интерференционной оптикой Номарского.

В результате наших исследований Ampelomyces quisqualis обнаружен на 10 видах Erysiphales, паразитирующих на семействах: Asteraceae, Lamiaceae, Hypericaceae, Brassicaceae, Rosaceae, Elaeagnaceae.

Ниже приводится список грибов и растений-хозяев, на которых был обнаружен Ampelomyces quisqualis.

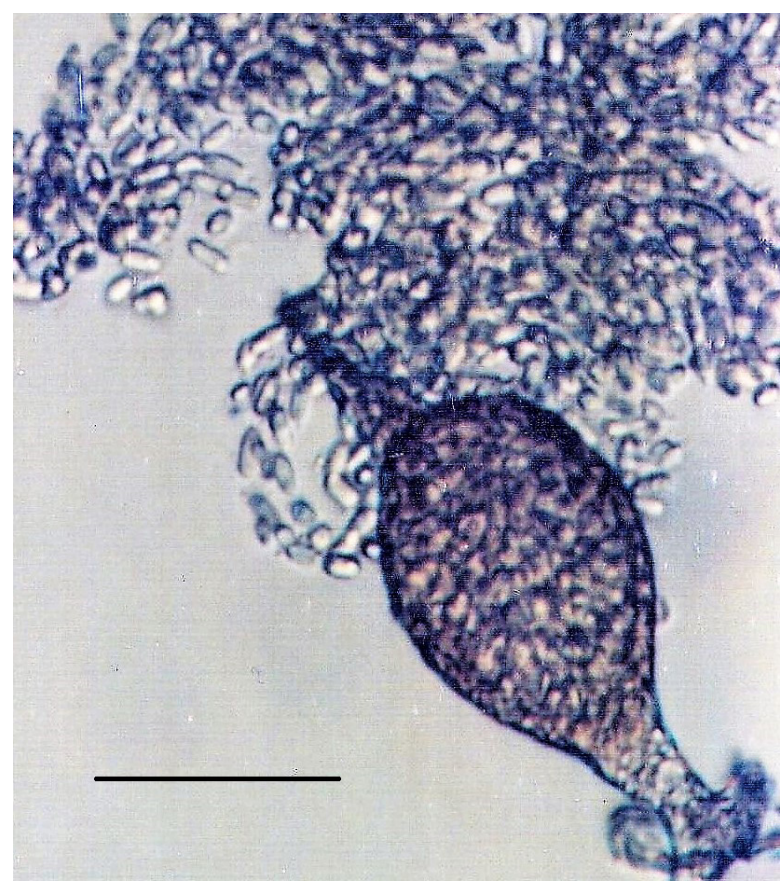

Рис. 1. Пикниды Ampelomyces quisqualis на Geum urbanum. - Шкала $=80 \mu \mathrm{m}$.

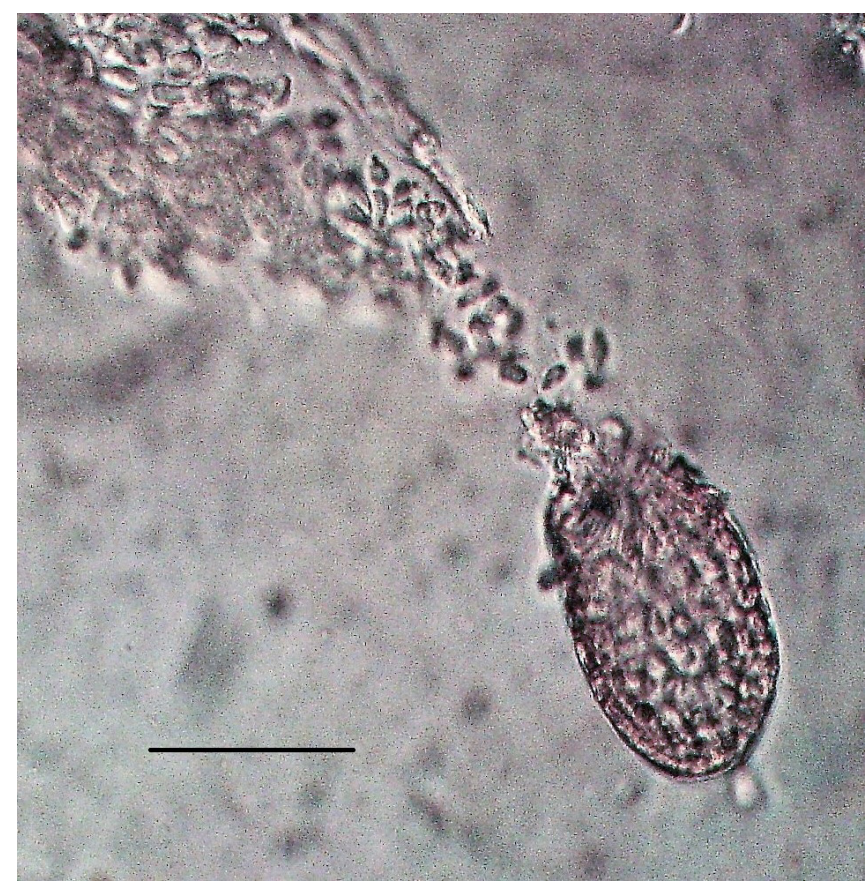

Рис. 2. Пикниды Ampelomyces quisqualis на Hieracum virosum. - Шкала $=90 \mu \mathrm{m}$. 
Erysiphe cichoracearum var. cichoracearum DC. - на Ligularia macrophylla (Ledeb.) DC., «Алматинская область, Карасайский р-н, Заилийский Алатау, Иле-Алатауский Государственный Национальный природный парк (ИАГНПП), ущ. Аюсай, склон юго-восточной экспозиции, еловый лес, т. 303,

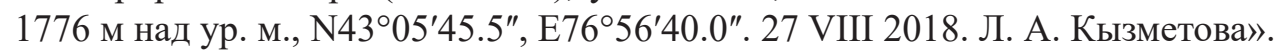

Erysiphe cichoracearum var. cichoracearum DC. - на Hieracium virosum Рall., «Алматинская область, Карасайский р-н, Заилийский Алатау, ИАГНПП, Большое Алматинское ущ., склон юго-западной экспозиции, еловый лес, т. 292, 2446 м над ур. м., N4303'40.7", E7659'07.7”, 03 IX 2018. А. М. Асылбек».

Erysiphe cichoracearum var. cichoracearum DC. - на Cicerbita azurea (Ledeb.) Beauverd., «Алматинская область, Карасайский р-н, Заилийский Алатау, ИАГНПП, ущ. Аюсай, склон юго-восточной экспозиции, еловый лес, т. 303, 1776 м над ур. м., N4305'45.5”, E7656'40.0", 27 VIII 2018, Л. А. Кызметова, там же, ущ. Аюсай, склон восточной экспозиции, еловый лес, т. 306, 1874 м над ур. м., N4305'31.4", E76 56' 53.2", 27 VIII 2018, У. К. Джетигенова».

Erysiphe biocellata Ehrenb. - на Stachys sylvatica L., «Алматинская область, Карасайский р-н, Заилийский Алатау, ИАГНПП, Большое Алматинское ущелье, гребень Большого Алматинского пика, смешанный лес, т. 310, 1504 м над ур. м., N4306'36.2", E7654'49.1", 29 VIII 2018, У. К. Джетигенова».

Erysiphe galeopsidis DC. - на Origanum vulgare L., «Алматинская область, Карасайский р-н, Заилийский Алатау, ИАГНПП, Большое Алматинское ущелье, гребень Большого Алматинского пика, березняк, т. 311, 1556 м над ур. м., N4306'31.4", E7654'43.8”, 29 VIII 2018, Л. А. Кызметова».

Erysiphe cruciferarum Opiz ex L. Junell - на Hypericum hirsutum L., «Алматинская область, Алматинский заповедник, Монахова щель, 1641 м над ур. м., N43²13'39.86", E77¹5'34.59", 07 IX 2012, Е. В. Рахимова».

Erysiphe communis f. arabidis Jacz. - на Arabis pendula L., «Алматинская область, хр. Заилийский Алатау, ур. Ассы, правый берег р. Ассы, N43¹9.19", E78¹6.46", 05 VIII 2012, Е. В. Рахимова».

Podosphaera fuliginea (Schltdl.) U. Braun \& S. Takam. - на Taraxacum sp., «Алматинская область, хр. Заилийский Алатау, ур. Ассы, правый берег р. Ассы, N43¹9.19", E78¹6.46", 06 VIII 2012, Е. В. Рaхимова».

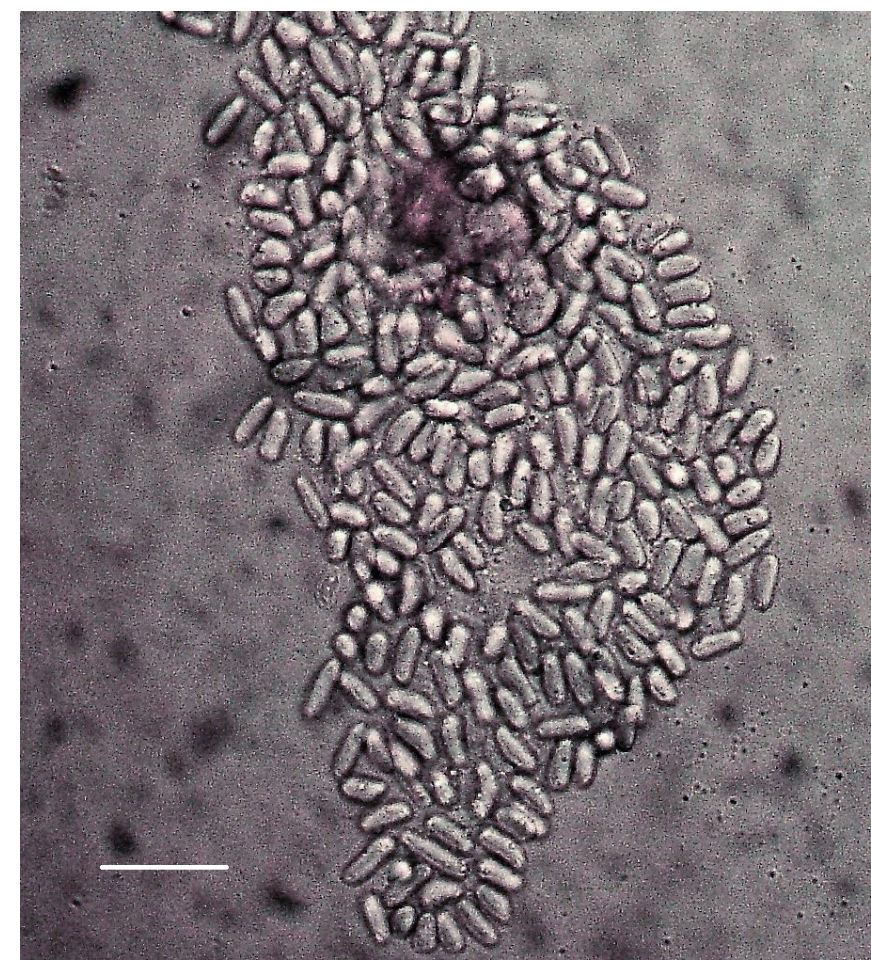

Рис. 3. Конидии Ampelomyces quisqualis на Cicerbita azurea. - Шкала $=13 \mu \mathrm{m}$.



Рис. 4. Конидии Ampelomyces quisqualis на Ligularia macrophylla. - Шкала $=15 \mu \mathrm{m}$. 
Sphaerotheca macularis f. gei Jacz. - на Geum urbanum L., «Алматинская область, хр. Заилийский Алатау, ур. Ассы, правый берег р. Ассы, N43¹9.19", E78¹6.46", 05 VIII 2012, Е. В. Рахимова».

Phyllactinia hippophaes Thüum. ex S. Blumer - на Hippophae ramnoides L., «Алматинская область, Карасайский р-н, Заилийский Алатау, ИАГНПП, ущ. Аюсай, склон юго-восточной экспозиции, еловый лес, т. 303, 1776 м над ур. м., N4305'45.5”, E7656'40.0”, 27 VIII 2018, Е. В. Рахимова».

Анализ полученных данных показал, что гиперпаразит чаще всего встречается на возбудителях мучнистой росы у растений семейства Asteraceae и Lamiaceae. Впервые Ampelomyces quisqualis обнаружен на возбудителях мучнистой росы на представителях семейств Elaeagnaceae и Hypericaceae. Гиперпаразит был обнаружен на 10 различных видах мучнисторосяных грибов, наиболее часто - на представителях рода Erysiphe.

Мицелий Ampelomyces quisqualis обнаружен на поверхности мицелия мучнисторосяных грибов, но чаще всего - в его гифах и конидиеносцах. Там же образуются одиночные, шаровидные или вытянутые, бледно-бурые, светло-коричневые или коричневые, однокамерные, пикниды гиперпаразита (рис. 1,2 ), иногда с сосочковидным апикальным выростом. Поверхность покрыта четким сетчатым рисунком. Размеры пикнид варьируют довольно значительно (табл. 1), в диапазоне 30,0-105,0 × 25,050,0 мкм. Размеры пикнид Ampelomyces quisqualis на различных хозяевах близки между собой, однако большие размеры пикнид наблюдаются на Hieracum virosum, а меньшие - на Stachys sylvatica. Конидии одноклеточные, прямые или слегка согнутые, чаще всего цилиндрические (рис. 3,4 ), тонкостенные, гладкие, почти бесцветные или со слабым буроватым оттенком, выделяются из пикнид сильной струей в виде ленты, образуя вокруг пикнид споровую массу. Размеры конидий варьировали от 3,5-7,0 × $1,5-3,5$ мкм.

Таблица

Морфометрическая характеристика отдельных структур Ampelomyces quisqualis

\begin{tabular}{|l|l|c|c|}
\hline \multirow{2}{*}{ Гриб-хозяин } & \multicolumn{2}{|c|}{ Растение-хозяин } & \multicolumn{2}{c|}{ Размеры } \\
\cline { 3 - 4 } & & пикнид & спор \\
\hline Erysiphe biocellata & Stachys sylvatica & $40,0-80,0 \times 30,0-40,0$ & $3,5-6,5 \times 1,5-2,5$ \\
\hline Erysiphe galeopsidis & Origanum vulgare & $55,0-95,5 \times 30,0-40,0$ & $4,5-6,5 \times 2,0-2,5$ \\
\hline \multirow{2}{*}{$\begin{array}{l}\text { Erysiphe cichoracearum } \\
\text { var. cichoracearum }\end{array}$} & Cicerbita azurea & $45,0-100,0 \times 30,0-50,0$ & $5,5-6,5 \times 2,0-2,5$ \\
\cline { 2 - 4 } & Hieracum virosum & $60,0-105,0 \times 30,0-50,0$ & $5,5-7,0 \times 2,5-3,5$ \\
\cline { 2 - 4 } & Ligularia macrophylla & $45,0-95,5 \times 30,5-40,5$ & $4,0-6,5 \times 2,5-3,0$ \\
\hline $\begin{array}{l}\text { Erysiphe communis f. } \\
\text { arabidis }\end{array}$ & Arabis pendula & $45,0-80,0 \times 30,0-40,0$ & $3,5-6,5 \times 2,0-2,5$ \\
\hline Phyllactinia hippophaës & Hippophae ramnoides & $40,0-100,0 \times 30,0-40,0$ & $4,0-6,5 \times 2,0-2,5$ \\
\hline Podosphaera fuliginea & Taraxacum sp. & $40,0-85,0 \times 30,5-45,0$ & $4,5-6,5 \times 2,0-2,5$ \\
\hline $\begin{array}{l}\text { Sphaerotheca macularis } \\
\text { f. gei }\end{array}$ & Geum urbanum & $30,0-90,0 \times 25,0-30,0$ & $4,0-6,5 \times 2,5-3,0$ \\
\hline
\end{tabular}

\section{ЛИТЕРАТУРА}

Бызова З. М., Васягина М. П., Деева Н. Г., Калымбетов Б. К., Писарева Н. Ф., Швариман С. Р. Флора споровых растений Казахстана. - Алма-Ата.: Наука, 1967. - 340 с.

Калымбетов Б. К. Микологическая флора Заилийского Алатау. - Алма-Ата.: Наука, 1969. - 468 с.

Мельник В. А. Определитель грибов России. - Санкт-Петербурз.: Наука, 1997. - 279 с.

Поликсенова А. К. Храмцов С. Г., Пискун В. Д. Методические указания к занятиям спец практикума по разделу «Микология. Методы экспериментального изучения микроскопических грибов» для студентов. - Минск.: БГУ, 2004. -36 с.

Рахимова Е. В., Нам Г. А., Ермекова Б. Д., Есенгулова Б. Ж. Микологические экскурсии по Заилийскому Алатау. - Алматы, 2014. -207 c.

Рудаков О. Л. Микофильные грибы, их биология и практическое значение. - М.: Наука, 1981. - 160 с.

Emmons $\boldsymbol{C}$. W. Cicinnobolus cesatii: a study in host-parasite relationships // Bull. Torrey Bot. Club., 1930. - Vol. 57. - P. 421-441. 